\title{
ラッコの妊娠後期における胎子死亡例
}

\author{
寺沢文男 $^{1 ｝ \text {, 戸田尚夫 }{ }^{1 ｝ \text {, 山本康夫 }{ }^{2)} \text {, 大西善久 }{ }^{3)} \text {, 大橋信明 }{ }^{4)}$ \\ 1）江ノ島水族館 † 251-0035 藤沢市片瀬海岸 2-17-25 \\ 2）下田海中水族館＝ 415-8502 下田市 3-22-21 \\ 3）大西犬猫病院 $=414-0032$ 伊東市音無町 2-1 \\ 4）大橋動物病院 = 251-0021 藤沢市鵠沼神明 3-3-21
}

(2002 12.10 受付, 20035.5 受理)

\section{Death of a Sea Otter Fetus in the Late Stage of Pregnancy}

\author{
Fumio Terasawa $^{12}$, Hisao Toda $^{1)}$, Yasuo Yamamoto ${ }^{2)}$, Yoshihisa OhNISHI ${ }^{3)}$ and Nobuaki OHASHI ${ }^{4)}$ \\ 1) Enoshima Aquarium, 2-17-25 Katase-kaigan, Fujisawa, Kanagawa 251-0035, Japan \\ 2) Shimoda Floating Aquarium, 3-22-21 Shimoda, Shizuoka 415-8502, Japan \\ 3) Ohnishi Dog and Cat Hospital, 2-1 Otonashi-cho, Ito, Shızuoka 414-0032, Japan \\ 4) Ohashi Animal Hospital, 3-3-21 Shinmei, Kugenuma, Fujisawa, Kanagawa 251-0021, Japan
}

\begin{abstract}
In the estimated 189th day of pregnancy, bleeding from the vagina of a sea otter (Enhydra lutris) was observed. From the previous day, she had stopped eating fish. According to the result of an X-ray test and her behavior, the fetus was suspected to have been dead. Oxytocin and $\mathrm{PGF}_{2 \alpha}$ were administered respectively. The doses for oxytocin were 5, 10 and 20 units, and $10 \mathrm{mg}$ for $\mathrm{PGF}_{2 \alpha}$. Vomiting and hyperventilation were observed after $\mathrm{PGF}_{2 \alpha}$ was administered. However, a miscarriage did not occur. A caesarean section was carried out, but the fetus had already died (total length $51.6 \mathrm{~cm}$; weight $193 \mathrm{~kg}$ ) The mother also died without recovering from isoflurane anesthesia( $5 \%$ for induction and 2-4\% for maintained).
\end{abstract}

Key words: sea otter, reproduction, caesarean section

Jpn. J.Zoo. Wildl. Med. 8(2) : 127-130, 2003

2000 年 12 月 31 日現在, 我が国では 27 園館でラッコ (Enhydra lutris) 88 頭(オス 36 頭, メス 52 頭)が飼育され, その内飼育下繁殖個体は 55 頭（オス 30 頭, メス 25 頭） である。飼育頭数は 1998 年 101 頭, 1999 年 95 頭で年々 減少が見られている $[1]$ 。飼育下繁殖が重要であるとされ る一方, 死産, 流産や子宮破裂も認められている [2]。難 産時の行動記載, 陣痛促進処置, 帝王切開などの報告は少 なく,未だよく知られていないラッコの妊娠に資するため,
妊娠末期に子宮内で胎子が死亡した症例を報告する。 本個体（国内登録番号 177）は推定 11 歳のメスで, 米 国アラスカにて捕獲され 1993 年 5 月 13 日よみうりラン ド海水水族館に搬入, 同館にて 5 回出産した。2002 年 3 月 12 日, 下田海中水族館へ移動, 同月 26 と 27 日に 成獣オス（国内登録番号 056, 1986 年 10 月 10 日来館） と交尾した。以後, 主にイカ, タラ, ウチムラサキを総量 で 1 日に $4.0 〜 5.2 \mathrm{~kg}, 9$ 月 30 日まで給慨した。 
飼育場所は，下田海中水族館のラッコ館に設営された室内 プール(幅 $13 \mathrm{~m}$, 奥行き $6 \mathrm{~m}$, 水量 $100 \mathrm{ton}$, 水深 $1.5 \sim 2.6 \mathrm{~m}$ ) で, 水温, 気温はともに周年でほぼ $13^{\circ} \mathrm{Cに}$ 保たれていた。 2002 年 10 月 1 日 8 時ごろ, オスとアクリル板越しに, 激しく威嚇し合っているのを目撃した。その後, プール隅 に漂い 2 日間食欲廃絶したままで，翌 2 日 20〜24 時ま で腟から 3 回出血するのが観察された。本症例では 21 日 間で平均捸䬣量 $0.45 \mathrm{~kg}$, その間に連続 4 日を 2 回, 合計 で 11 日完全絶食した。

海棲哺乳類の外科的処置および術後管理の難しさを考慮 し内科的治療を行うこととした。第 4 病日（10月 6 日）, 網で捕獲し治療した。使用薬剤は, オキシトシン（アトニ ン ${ }^{\circledR}-\mathrm{O}$, 帝国蔵器） 5 単位, 硫酸イセパマイシン（エルパ シン ${ }^{\circledR}$, 大洋薬品工業） $800 \mathrm{mg}$, スルピリン（メチロン ${ }^{\circledR}$, 第一製薬） $1.5 \mathrm{~g} ，$ プレドニゾロン（プレドニゾロン注射 液 ${ }^{\circledR}$ ，田村製薬） $50 \mathrm{mg}$ であった。体温は $38.7^{\circ} \mathrm{C}$ （プロー
ブ約 $20 \mathrm{~cm}$ 挿入)であり, 以後 21 日まで連日治療を続けた。 主に投与したのは, 硫酸イセパマイシン $800 \mathrm{mg}$ とアンピ シリンナトリウム・クロキサシリンナトリウム（注射用ビ クシリン ${ }^{\circledR} \mathrm{S}$, 明治製菓) $2 \mathrm{~g}$ の 2 種類の抗生物質で, 体温 測定も行った。その值によってスルピリンを追加投与した。 その結果, 7 日 $38.2^{\circ} \mathrm{C}, 8$ 日 $37.7^{\circ} \mathrm{C}$ と解熱効果を示した。

第 7 病日（10月 9 日), レントゲン検查で胎子の存在 を確認した（図 1)。オキシトシン 5, 10, 20 単位を同 日より 3 日間投与し, さらに 17 日にプロスタグランジ ン $\mathrm{F}_{2 \alpha}$ (プロナルゴン ${ }^{\circledR} \mathrm{F}$, ファルマシア・アップジョン) $10 \mathrm{mg}$ を投与した。

オキシトシン投与については, 5 単位を 2 回, 10 単位, 20 単位の合計 4 回の投与を行った。いずれの場合も, 投 与後 3〜 14 時間にはグルーミングをしながら, 激しい前 方回転を認め, その行動は 20 分〜 1 時間近くに及んだ。 最初の 5 単位 1 回の投与時を除き, それぞれで 2 回以上

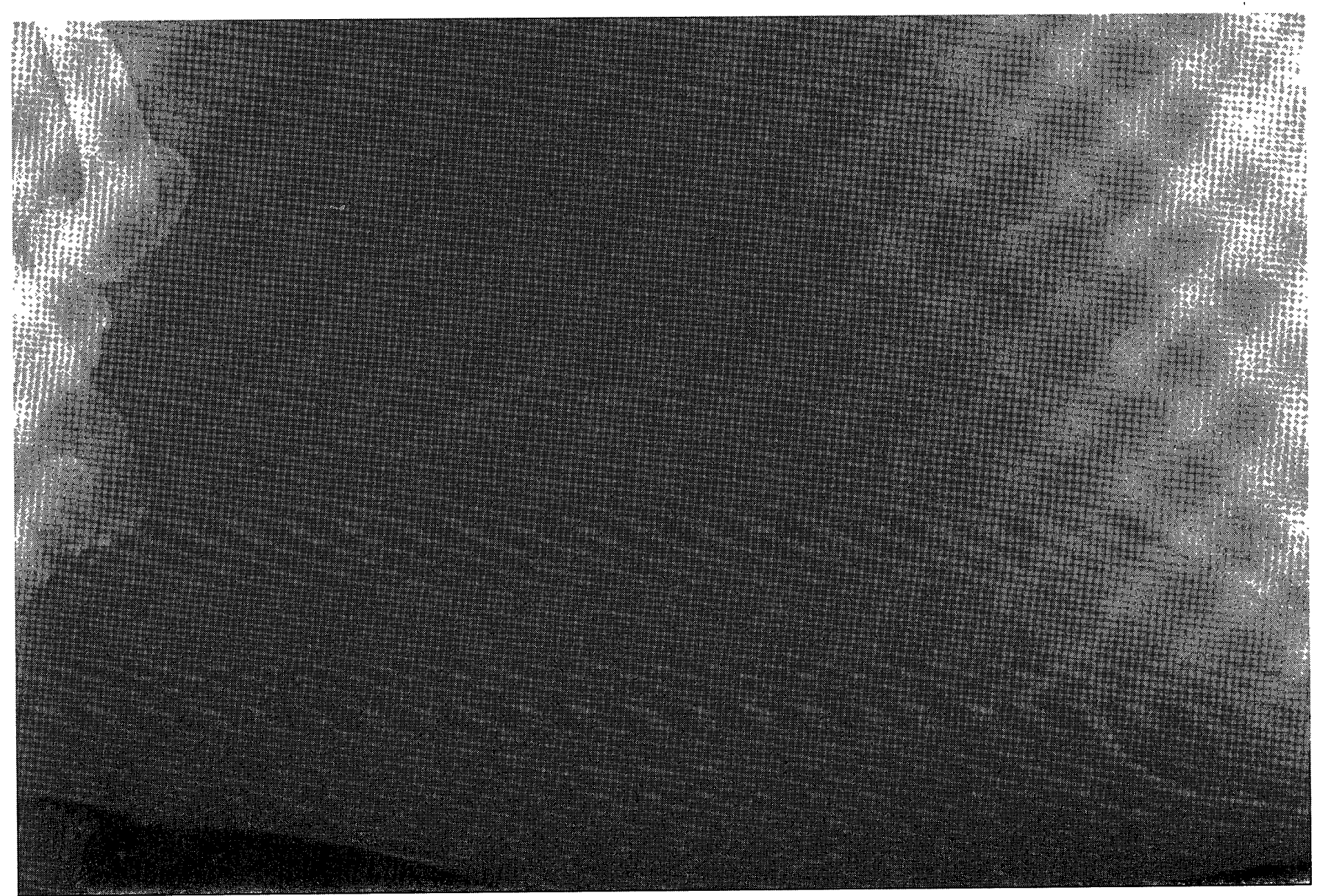

図 1 X 線単純撮影によるラッコ胎子 


\section{ラッコ妊娠異常}

同様の行動を認めた。投与後 10 時間には乳頭がさらに突 出しているのも観察された。

プロスタグランジン $\mathrm{F}_{2 \alpha} 10 \mathrm{mg}$ の投与では, 投与後 30 分ごろより瞳孔散大, 腹部波動が認められた。オキシトシ ンの出産兆候とは異なり, 後脚を伸ばして上半身で力む行 動が見られた。また，呼吸促進も認めた。さらに，投与後 3 時間には 7 回嘔吐し, 最終的に衰弱して陸上で横たわっ てしまった。外観的な行動から, 明らかに元の状態に戻っ たのは，投与後 24 時間以上経過してからであった。

上記の内科的治療では分婏が困難であったため, 外科的 方法による胎子摘出を試みた。ケージ $(60 \times 85 \times \mathrm{H} 70$ $\mathrm{cm})$ をビニールシートで密封しイソフルレン (イソフル ${ }^{\circledR}$, 大日本製薬） $5 \%$ ，酸素 61/ 分を注入した。導入時間は 15 分であった。不動化後，仰臥位に保定しマスク装着して同 麻酔 2 〜 \% で維持した。臍より腹部正中線上を下方に, 幅 $1 \mathrm{~cm}$, 長さ $25 \mathrm{~cm}$ に剪毛, 同部位を $20 \mathrm{~cm}$ 開腹した。 子宮体を切開し死亡した胎子を摘出した。子宮は茶褐色, 脆弱化していたため, 卵巣子宮摘出術を実施した。左右の 卵栄血管を結禁して卵巣を切離し, 子宮頸管部を結禁切除 した。血液を混じた多量の腹水, 腐敗臭を伴い腹膜炎も併 発していた。腹腔内を洗浄後, 腹膜および筋膜は単純結節 縫合, 皮膚は埋没縫合を施した。しかしながら, 母獣は麻 酔から覚醒することなく死亡した。体重は $22.3 \mathrm{~kg}$ であっ た。

今回, 出産を促進させる目的で, オキシトシンとプロス タグランジン $\mathrm{F}_{2 \alpha}$ の投与を試みた。下田海中水族館では出 産兆候の一つとして，グルーミングをしながら生殖孔を舐 め, 激しく前転する行動をしばしば目撃してきた。また, 分娭は 1 時間ほど前より行動 [6]に表れ，水面で全身を伸 ばした姿勢で緩慢で単調な連続的横転および前転運動があ り生殖孔部分のグルーミングが多くなった [3]。オキシト シン投与後の反応は, その行動に類似しており, 扔そらく 子宮収縮効果があったものと判断した。オキシトシン常用 量は, イヌで $5 \sim 20$ 単位, ネコで 3〜 5 単位である [4]。 我々は前者の量を選択したがいずれの量でも顕著な反応が 認められ，どれも自然に近い陣痛促進が見られた。

プロスタグランジン $\mathrm{F}_{2 \alpha}$ はほとんどの投与量で, 嘔吐, 下痢, 呼吸促進, 流涎, 低体温などの副作用 [4] が知ら れている。本症例でも, 嘔吐と呼吸促進が観察された。プ ロスタグランジン $\mathrm{F}_{2 \alpha} 1$-THAM 塩 $0.5 \sim 1.0 \mathrm{mg} / \mathrm{kg}$ を 24
時間間隔で 2 回皮下注射すると流産するとの報告［5］が あるが，前述のように副作用が強かったのでプロスタグラ ンジン $\mathrm{F}_{2 \alpha}$ 約 $0.45 \mathrm{mg} / \mathrm{kg}$ 筋肉内投与 1 回のみとした。

今回の結果から, 妊娠末期においてラッコで陣痛促進 を目的とする際には，オキシトシン 5 ～ 20 単位を投与し プールに戻すことが薦められる。一方，プロスタグランジ ン $\mathrm{F}_{2 \alpha}$ は副作用を生じることがあるので使用しないことが 望まれる。

三津シーパラダイスでの 11 例では, 妊娠期間が 193〜 234 日であった $[6] 。$ 腔から出血の見られた 10 月 2 日は, 最後に交尾が確認された 3 月 27 日から計算して 189 日 目であった。また, 摘出胎子（図 2) はオスで, 大きさは 全長 $51.6 \mathrm{~cm}$, 体重 $1.93 \mathrm{~kg}$ であった。ラッコ新生子の大 きさは出産時体長 $50 \mathrm{~cm}$ ほどで, 体重は約 $2 \mathrm{~kg}$ である [3] とされる。本例の胎子は, 既報の新生子の大きさと比較し ても十分成長していたと考えられる。胎子が子宮内で死亡 した原因については未だ不明である。

生前のレントゲン検査では頭位ではあるが, 胎子の頭部 が産道側を向かずに, 自分の腹部側に丸まっていた（図 1)。 妊娠末期になると，ほとんどの哺乳類では頭部が産道側に 向いてくる。本例では, すべてのレントゲン像で頭部の向 きが同じ方向であり, 撮影時点すでに死亡していたことが 示唆された。オキシトシンおよびプロスタグランジン $F_{2 \alpha}$ 投与後の母体の反応から, 明らかな子宮収縮が予測された にも関わらず出産までには至らなかったのは, 不正胎子体 位による可能性が考えられた。

本症例を含めて, 我が国ではラッコの帝王切開が少な

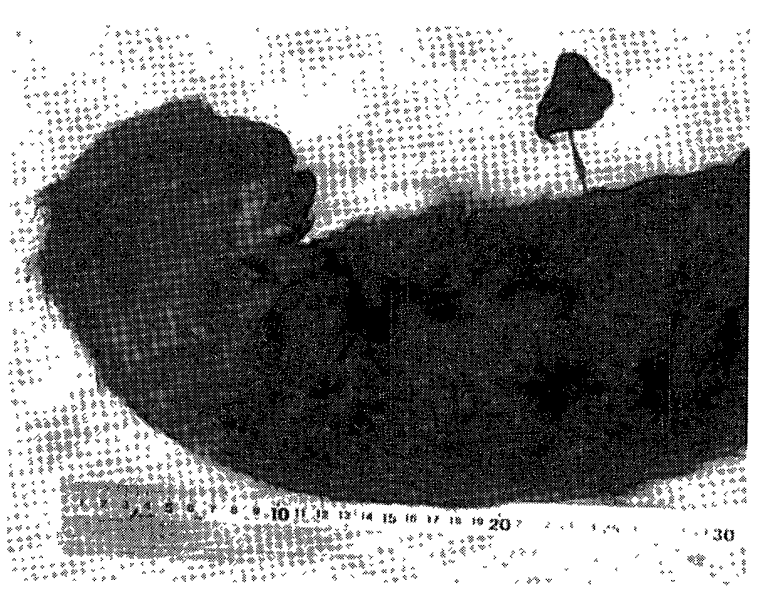

図 2 摘出後の胎子 
くとも 4 例 $[2,7]$ 行われており, 成功したのは 1 例のみ [7]である。それと本例を比べると麻酔薬と術式は同様で, Williams ら [8］もラッコの麻酔にイソフルレンを使って いる。大きな違いは, 成功例 [7] では外陰部から出血を 見た翌日に帝王切開を行い, 我々は内科的治療を優先させ たため中 18 日間あった。前者 [7] では胎子はすでに死 亡しており，扔そらく本症例でも胵から出血が見られた時 には死亡していた可能性がある。

他の海獣類のように愿い皮下脂肪の層を持たないラッコ は，体重の $20 ２ 5 \%$ の餌を摂慨している [3]。これま では 48時間の完全絶食が限界であると考えられていたが, それ以上の絶食を可能にしたことの一つとして，妊娠に伴 い皮下および体壁腰部には多量の脂肪が蓄積されていた。 おそらく，蓄積脂肪を栄養源にしていたと思われる。成功 例 ［7］では術後回復までに48 日を費やした一方で，本 症例では 21 日間ほとんど食べなかった。外科的処置を優 先させた場合, 絶食だけを考えると, 術後管理の半分近く の期間を耐えうるだけの体力を蓄えていたことが予測され た。

\section{要 約}

推定妊娠 189 日目のラッコ（Enhydra lutris）が胵より 出血した。その前日より食欲廃絶し, 以後摂䬣不良となっ た。レントゲン検査や母獣の行動から胎子の死亡を疑つ た。オキシトシン $5,10,20$ 単位，プロスタグランジン $\mathrm{F}_{2 \alpha} 10 \mathrm{mg}$ をそれぞれ投与したが, 出産までには至らなかっ た。帝王切開により死亡した胎子（オス, 全長 $51.6 \mathrm{~cm}$,
体重 $1.93 \mathrm{~kg}$ ) 摘出を行ったが,母獣も麻酔（イソフルレン, 導入 $5 \%$, 維持 $2 \sim 4 \%)$ から覚醒することなく死亡した。 キーワード : ラッコ, 繁殖, 帝王切開

\section{謝辞}

本稿を終えるにあたり，日本獣医畜産大学河上栄一先生 には適切な御助言と共に，プロスタグランジン $\mathrm{F}_{2 \alpha}$ を御提 供して頂いた。同大学織間博光先生, 藤田道郎先生からレ ントゲン機材を借用した。最後に，江ノ島水族館堀由紀子 館長，下田海中水族館児玉正志館長，両水族館飼育一同， 大橋動物病院スタッフならびに関係者各位には感謝する。

\section{引用文献}

1 古田正美. 2001. ラッコの繁殖計画・個体登録. 第 12 回種保存会議並 びに種保存委員会経過報告. 日本動物園水族館協会, 東京.

2 古田正美. 2000 ラッコ国内血統登録調査報告. 日本動物園水族館協会, 東京

3 中島将行. 1990 ラッコの生活 海の哺乳類-その過去・現在・未来- (宮 崎信之, 粕谷俊雄編）, pp 218-228 サイエンティト社, 東京

4 Burke TJ 1986 Small Animal Reproduction and Infertılity A Clinical Approach to Diagnosis and Treatment, Lea \& Febiger

5 Christiansen IbJ 1984 Reproduction in the Dog and Cat, Bailliere Tindall

6 中島将行, 古田彰, 藤巻康年, 山田二郎. 1988 伊豆三津シーパラダイ スにおけるラッコの繁殖. 動水誌 30(2) 48-63

7 大池辰也, 廣田大輔, 重井明男, 佐々木勝美, 神田美樹, 高橋健次. 1997. 娃娠末期に異常を認めたラッコの治療例について I 吸入麻醉薬を 用いた検查と開腹術. 動水誌 38(4). 128.

8 Williams TD, Williams AL, Stoskopf M 1990 Marine mammal anesthesia In CRC Handbook of marine mammals medicine. Health, Disease, and Rehablltation (Dierauf L A, ed), pp 175-191, CRC press, 735 pp 